\title{
The Myth, the Truth, and What Security Council Resolution 1973 Changed:The Use of Force for the Protection of Human Rights
}

\author{
El mito, la verdad y lo que la resolución 1973 \\ del Consejo de Seguridad cambió: el uso de la fuerza \\ para la protección de los derechos humanos
}

Luis Jardón

\begin{abstract}
SUMmARY: I. The prohibition on the use of force and the myth of humanitarian intervention. II. The authorization for the use of force for the protection of human rights as a legal truth. III. Resolution 1973: a fundamental change.
\end{abstract}

* Artículo recibido el 5 de julio de 2011 y aprobado para publicación el 28 de septiembre de 2011.

** Law degree (CIDE), LL.M. (Cantab). 
Resumen: En este trabajo se evalúa el debate a largo plazo sobre la legalidad del uso de la fuerza para la protección de los derechos humanos. En virtud de una interpretación de la Carta, la intervención humanitaria es, a priori, rechazada como una medida legal para proteger los derechos humanos, pero la legalidad de la autorización del Consejo de Seguridad para el uso de la fuerza por razones humanitarias es argumentada. No obstante, en una interpretación de la Carta de la ONU y un análisis de la práctica del Consejo, el documento propone que las autorizaciones encuentran su límite en el principio de soberanía territorial y el consentimiento del Estado territorial. La autorización para el uso de la fuerza en la resolución 1973 es la primera que fue adoptada sin el consentimiento del Estado territorial, cambiando, por lo tanto, la interpretación de la Carta y la jerarquía de los principios que durante muchos años gobernaron las relaciones internacionales.

Palabras clave: uso de la fuerza, derechos humanos, Carta de las Naciones Unidas, Consejo de Seguridad, principios de derecho internacional.

ABSTRACT: This paper assesses the long-lasting debate over the legality of the use of force for the protection of human rights. Under an interpretation of the Charter, humanitarian intervention is a priori dismissed as a legal measure to protect human rights, but the legality of the Security Council authorization for the use of force for humanitarian purposes is asserted. Nevertheless, under an interpretation of the UN Charter and an analysis of the Council's practice, the paper proposes that such authorizations find their limit on the principle of territorial sovereignty and the consent of the territorial state. The authorization for the use offorce in Resolution 1973 is the first that was adopted without the consent of the territorial state, changing, as such, the interpretation of the Charter and the hierarchy of principles that for many years governed international relations.

Descriptors: Use of Force, Human Rights, United Nations Charter, Security Council, Principles of International Law.

RÉSUMÉ: Cette étude évalue le débat à long terme sur la légalité de l'utilisation de la force pour protéger les droits humains. Sous une interprétation de la Charte, l'intervention humanitaire est, a priori, non acceptée comme une action juridique pour protéger les droits humains, mais la légalité de l'autorisation du Conseil de Sécurité pour l'utilisation de la force pour des raisons humanitaires ont des arguments. Cependant, dans une interprétation de la Charte des Nations Unies et une analyse de la pratique du Conseil, le document propose que les autorisations trouves des limitées dans le principe de la souveraineté territoriale et le consentement de l'Etat territorial. L'autorisation pour l'usage de la force dans la Résolution 1973 est la première qui a été adopté sans le consentement de l'État territorial, en changeant, l'interprétation de la Charte et la hiérarchie des principes que pendant beaucoup d'années ont gouverné les relations internationales.

Mots-clés: usage de la force, droits de l'homme, Charte de l'ONU, Conseil de Sécurité, principes du droit international. 
The aftermath of NATO's intervention in Kosovo was characterized by academic discussions addressing its legality and, in broader terms, the capacity of states to use force against the territory of another state for the protection of civilian population. Debates over these issues intensified as a consequence of the Darfur crisis and were recently renewed due to the conflict on Libya.

To address these conflicts some commentators have consistently sustained the legality of the use of force by a state on the territory of another for the protection of civilian population. Under this approach, known as humanitarian intervention, human rights constitute an entitlement for the use of force when civilian population is threatened.

Within the political arena, this issue was addressed by the High Level Panel Report on Threats, Challenges and Change and the Future Role of the United Nations Security Council. ${ }^{1}$ The Report endorses the recently developed doctrine of Responsibility to Protect and, in particular, the idea that the UN Security Council (SC) may authorize the use of force for the protection of the civilian population as a measure of last resort. The UN State Members supported this theory in the 2005 World Summit Outcome. $^{2}$

However, as a matter of legal interpretation, the use of force for the protection of civilians has to be analyzed under two perspectives. First, as the unilateral use of force capable of constituting an exception to Article 2 (4) of the UN Charter ${ }^{3}$ or, second, as a measure that the SC can undertake in accordance with its powers under Chapter VII of the UN Charter. ${ }^{4}$ Whereas the factual outcomes are essentially the same, the entitlements and the legal consequences arising for the use of force under one or the other basis vary substantially. This article will explore the legal issues arising from both regimes.

1 High Level Panel Report on Threats, Challenges and Change and the Future Role of the United Nations Security Council 2004, UN Document A/59/565; See also, Report of the Secretary General, In Larger Freedom, para 125.

2 World Summit Outcome Document 2005, UN Document A/60/L.70

3 Charter of the United Nations 26 June 1945, 3 Bevans 1153

4 Gray, Christine, "The Charter Limitations on the Use of Force: Theory and Practice" in Lowe, Vaughan, et. al (eds.), The United Nations Security Council and War, New York, OUP, 2008, 86. 
Nevertheless, human rights, as legal norms, are not relevant elements to assess the legality of the use of force neither under Article 2(4) of the UN Charter nor under the Chapter VII scheme. Whereas the legality of the use of force under Article 2(4) can only be construed under the article itself and the exception provided in article 51, the legality of the SC actions under Chapter VII has to be interpreted in accordance with the provisions of the UN Charter that delimit its functions and the principles of the Organization itself.

In order to explore the so-called concept of humanitarian intervention, Section I of this work distinguishes from the legal regime on the prohibition of the use of force applicable to states and the regime that empowers the SC to authorize it. It submits that a false legal dichotomy exists between the prohibition of the use of force and the protection of human rights and that it is caused by a wrong method to approach the relationship between one and another. Under a treaty interpretation scheme, the idea that human rights are valid legal justifications for the unilateral use of force of one state against another is rejected and, thus, the invalidity of the concept is asserted.

Conversely, Section II of this paper is developed under the notion that the SC is entitled to authorize the use of force for the protection of human rights. Nevertheless, such entitlement is political and not legal. Whereas its legal capacity to authorize the use of force finds it basis in Chapter VII of the UN Charter, this Section submits that Council's authorizations of the use of force for the protection of human rights are legally restricted by the principle of consent of the territorial state. It further elaborates on the complete practice of the Council in this matter in order to sustain this hypothesis.

Despite academic debates, such interpretation of the UN Charter regimes on the use of force represented the state of the art on the matter, as the practice of states and the SC reflected. Council's authorization of the use of force provided in Resolution 1973 altered such interpretation for the very first time.

SC Resolution 1973 on the conflict in Libya is the first which authorizes the use of force in the territory of a UN Member State without its consent. This significantly alters the principles under which the Organization was conceived and poses questions on how this precedent will 
affect the future practice of the SC and its interpretations of the UN Charter.

There are certainly many relevant aspects of NATO's actions in Lybia, such as the situation that lead to its adoption, the specific obligations arising for states from the Resolution 1973 and its interaction with the SC. However, Section III of this paper will only focus on the normative impact of the authorization of the use of force, in regard with the previous practice of the SC and the intepretation of legal regimes contained the UN Charter.

\section{THE PROHIBITION ON THE USE OF FORCE AND THE MYTH OF HUMANITARIAN INTERVENTION}

The International Court of Justice (ICJ) emphatically affirmed in the Armed Activities case that the prohibition of the use of force is a cornerstone of international law. ${ }^{5}$ This prohibition is contained in article 2(4) of the UN Charter which establishes that "[a]ll Members shall refrain in their international relations from the threat or use of force against the territorial integrity or political independence of any state, or in any other manner inconsistent with the Purposes of the United Nations.”

During the Cold War years, Professors Michael Reisman and Oscar Schachter engaged in a vigorous debate on the adequacy of this provision. The former ascertained that the collective security system had collapsed due to the SC inactivity as a stemming from the war and, therefore, a narrow interpretation of Article 2(4) should be endorsed in order to allow states to use force when required for security purposes. Conversely, Professor Schachter believed that such position could create serious consequences for the community of states since it would

Armed Activities on the Territory of the Congo (Democratic Republic of the Congo v. Uganda), Judgment, ICJ Reports 2005, p. 168, para 148 [Hereinafter “Armed Activities case”]. In the Nicaragua case the ICJ had already asserted the customary nature of this rule. Military and Paramilitary Activities in and against Nicaragua (Nicaragua v. United States of America), Merits, ICJ Reports (1986), p. 14, para 190 [Hereinafter “Nicaragua case”]. 
entitle individual states to determine the international ordre public. ${ }^{6}$ This debate did not echo in the positions of states or their interpretation of the UN Charter. On the contrary, the international collective security system as it stands showed to be appropriate to address the situations in which the SC was unable to act and, generally, to the responses when faced with an eventual illegal use of force.

The abovementioned was possible mainly due to the decision of the ICJ in its Certain Expenses advisory opinion, which stated that in accordance with Article 24 of the UN Charter the SC has "primary but not exclusive responsibility for the maintenance of international peace and security". ${ }^{7}$ This led the UN General Assembly (GA) to issue the infamous Uniting for Peace Resolution which allowed it to take action when the SC was seized and politically deadlocked during the Suez Canal crisis. ${ }^{8}$ Moreover, the capacity of the system to address collective security issues has also proven to be true in the cases where a matter was both before the SC and the ICJ as occurred, inter alia, in the Hostages, Nicaragua, Lockerbie, and Legality of Use of Force cases. ${ }^{9}$

While not a new idea, as a result of the terrible series of events in Rwanda and the Balkans during the 1990s, some commentators espoused that force should be allowed for the protection of human rights. Within academic circles this concept has become to be known as humanitarian intervention.

6 Reisman, Michael, "Coercion and Self-Determination: Construing Charter Article 2(4)”, 78 AJIL 642, 2005; Schachter, Oscar, "The Legality of Pro Democratic Intervention”, 78 AJIL 646.

7 Certain expenses of the United Nations (Article 17, paragraph 2, of the Charter), Advisory Opinion of 20 July 1962: I.C. J. Reports 1962, p. 151; 163.

8 GA Res. 1000 (ES I) of 5 Nov. 1956; see also, Zaum, Dominik, "The Security Council, the General Assembly, and War: The Uniting for Peace Resolution”, in Lowe, Vaughan, et al. (eds.), The United Nations Security Council andWar, New York, OUP, 2008, 154.

9 United States Diplomatic and Consular Staff in Tehran, ICJ Reports (1980) p. 3 [hereinafter "Hostages case"]; Nicaragua, op. cit. 6; idem; Questions of Interpretation and Application of the 1971 Montreal Convention arising from the Aerial Incident at Lockerbie (Libyan Arab Jamahiriya v. United Kingdom), Preliminary Objections, Judgment, ICJ, Reports 1998, p. 9; Questions of Interpretation and Application of the 1971 Montreal Convention arising from the Aerial Incident at Lockerbie (Libyan Arab Jamahiriya v. United States of America), Preliminary Objections, Judgment, I. C. J. Reports 1998, p. 115 ; Legality of Use of Force (Serbia and Montenegro v. Belgium), Preliminary Objections, Judgment, ICJ Reports 2004, p. 279. 
The fundamental problem with the concept of humanitarian intervention is one of method and not of law. Most of the scholars that have analyzed it have done so trying to answer the question on whether the protection of human rights can justify the use of force. ${ }^{10}$ This question has created discussions under the erga omnes nature or peremptory status of certain human rights and their capacity to generate legal entitlements for the use of force. ${ }^{11}$ This is a false question and the method is incorrect. In these circumstances, they have also led to two major misinterpretations of the law applicable to the use of force.

The first of these misinterpretations is a consequence of the creation of artificial academic concepts such as "unilateral intervention" or "collective intervention" to determine under which circumstances the use of force may be justified for the protection of human rights ${ }^{12} \mathrm{~A}$ unilateral use of force in the territory of another state is a breach of Article 2 (4) and collective enforcement authorized by the SC derives from its Chapter VII powers. The SC powers under Chapter VII are not an exception to Article 51, but a regime in and of itself. Even if those powers are nowadays exercised through authorizations to Member States for the use of force, such capacity is exclusive of the SC, as the text of the UN Charter clearly stipulates. It is the organ that, in principle, has to command such operations.

In these circumstances, those are the legal bases that must be analyzed to determine the legality of the use of force and not the purposes for exercising it. The purposes of either forms of the use of force are irrelevant for determining their legal entitlement for the use of force.

10 See Mani vs "Humanitarian Intervention Today", (2005) 328 RCADI 9; Chesterman, Simon, JustWar or Just Peace? Humanitarian Intervention and International Law, New York, OUP, 2001; Greenwood, Christopher, Humanitarian Intervention: Law and Policy, New York, OUP, 2001; Tesón, Fernando, Humanitarian Intervention: An Inquiry into Law and Morality, New York, Transnational Publishers, 1997.

11 See Tomuschat, Christian, and Thouvenin, Mark (eds.), The Fundamental Rules of The International Legal Order: Jus Cogens and Obligations Erga Omnes, Leiden, Martinus Nijhoff, 2006; Orakhelashvili, Alexander, Peremptory Norms in International Law, New York, OUP, 2006; Tams, Christian, Enforcing Obligations Erga Omnes in International Law, Cambridge, CUP, 2005.

12 For example, see Dinstein, Yoram, "Humanitarian Intervention from Outside, In the Face of Genocide, Is Legitimately Only When Undertaken by the Security Council”, 27 Justice $5,2001$. 
The problem of adopting such method is that it undermines the structure of the legal regimes regarding the use of force contained in the UN Charter as they are analyzed in accordance with an external element in this case human rights -and, conversely, not within themselves.

Under the UN Charter the regimes for the use of force are mutually exclusive and do not require external concepts for their application. On the one hand there is a rule contained in Article 2 (4) prohibiting the use of force between states and its exception contained in Article 51 which permits the use of force when states exercise their inherent right to self-defence. On the other hand there is a rule contained in Article 42 giving the SC the power to authorize the use of force when it has determined the existence of a threat to the peace, a breach of the peace, or an act of aggression, pursuant to Article 39. The two regimes are mutually exclusive. ${ }^{13}$ This is so because they were drafted under different legal bases. The regime of Articles 2(4) and 51 is based on the principle that a state can do everything which is not prohibited by international law, ${ }^{14}$ whereas Chapter VII is based on the principle that international organizations can only undertake actions if they have the power to do so in accordance with its constituent instrument. ${ }^{15}$ Both principles ultimately derive from state sovereignty as the core principle of international law.

The second of these misinterpretations arises when interventions are analyzed under the purposes that the commentator believes the state or organization is pursuing and not under the actual legal entitlement which led to the use of force. This causes a purpose-based classification of interventions, which does not necessarily reflect the legal basis by which force was used. Under this approach, whether force is derived either from a unilateral action of the state, a SC authorization, a regional organization action, or as a consequence of a peacekeeping mission

13 Gray, Christine, International Law and the Use of Force, 3rd ed., New York, OUP, 2008, 49.

14 S.S. Lotus (Turkey v France) (1925) PCIJ Rep, Series A, no. 10, 18; See Chesterman, Simon et al., Law and Practice of the United Nations, New York, OUP, 2008.

15 Reparation for injuries suffered in the service of the United Nations, Advisory Opinion: I.C. J. Reports 1949, p. 174, 180; Pellet, Alain, "Peut-on et doit-on contrôler les actions du Conseil de sécurité?", in S.F.D.I., Le chapitre VII de la Charte des Nations Unies et les nouveaux aspects de la sécurité collective, Paris, Pedone, 1995, pp. 221-238. 
or its protection is irrelevant since the assessment favours a particular outcome. This methodological approach evidently undermines the position of the state, since the actual legal entitlement by virtue of which it uses force is not taken into consideration. Such an analysis is inherently reckless because it obviates the fact that only state practice is relevant for interpreting a treaty provision. In order to do so it is necessary to understand the legal position of the state on the matter and not just to observe the facts surrounding the use of force.

In this sense, in order to answer, not whether according to international law humanitarian intervention is allowed, but rather whether the use of force for the protection of human rights is legal, two questions must be addressed: 1) does the prohibition on the use of force contained in Article 2(4) has other exceptions than that established in Article 51?; and 2) does Chapter VII empowers the SC to authorize the use of force for the protection of human rights? The answer to the former is absolutely no. The answer to the latter is yes, but under the restrictions imposed by the Charter itself. This will be analyzed in Section 2 of this paper.

Despite its customary nature, the prohibition of the use of force is a treaty-based rule which must be assessed in accordance with the canons of interpretation prescribed by international law. These canons are established in the Vienna Convention on the Law of Treaties (VCLT).

Article 31 of the VCLT, which was recognized by the ICJ as a rule of customary international law in its Pulau Ligitan and Pulau Sipadan case, ${ }^{16}$ establishes that "[a] treaty shall be interpreted in good faith in accordance with the ordinary meaning to be given to the terms of the treaty in their context and in the light of its object and purpose". This is the method that international law has for interpreting international agreements and it is in accordance with this provision that Article 2(4) should be interpreted. ${ }^{17}$

16 Sovereignty over Pulau Ligitan and Pulau Sipadan (Indonesia / Malaysia), Judgment, I. C. J. Reports 2002, p. 625; p. 635, para 37.

7 Jennings believes interpretation is a science. See Jennings, Robert, "General Course on Principles of International Law", 121 RCADI 323; Conversely, Ameransinghe classifies it as an art. See Amerasinghe, CF, "Interpretation of Texts in Open International Organzations”, 65 BYBIL 175, 1994. Pellet believes that both an "espirit de finesse" and an "espirit de gèomètrie are required to interpret a treaty. See Pellet, Alain, Tenth report on reservations to treaties, Addendum, International Law Commission, Fifty-seventh session, UN Doc A/CN.4/558/Add 1 para 90. 
It is not possible to undoubtedly ascertain that the prohibition of the use of force is absolute by the mere text of Article 2 (4). This is so because it contains an explanatory phrase proscribing the use of force "against the territorial integrity or political independence of any state, or in any other manner inconsistent with the Purposes of the United Nations." This phrase can be interpreted as a prohibition of the use of force only for those purposes or as an absolute restriction. Despite this, the rule contained in Article 31 of the VCLT has to be considered as a unity and, as such, the context from which a specific treaty derives has to be taken into consideration in light with of its object and purpose.

Paragraph 2 of Article 31 establishes that for determining the context of a provision the preamble of the treaty has to be taken into consideration. Moreover, the ICJ supported in the SouthWest Africa and the Avena cases that the context of a provision should also be determined in accordance with other articles of the treaty itself. ${ }^{18}$ In this regard, whereas the preamble of the UN Charter submits that one of the purposes of the UN is the prevention of war, it also states the protection of human rights as one of them. Nevertheless, the only provision relating to the use of force vis-à-vis states is Article 51 which restates the inherent right that any state has to self-defence as the only explicit exception to the prohibition of the use of force between states.

Paragraph 3 (a) establishes that any subsequent agreement as to its application is also relevant for this task. Being GA resolutions agreements of UN Member States conducted under the rules imposed by the UN Charter, they may be considered valid to interpret it. This is confirmed by the ICJ decision on its Nuclear Weapons advisory opinion, in which it ascertained they have a normative value. ${ }^{19}$ In this regard, both the resolution on Friendly Relations and Cooperation Among States and on

On the interpretation of treaties see generally, Gardiner, Richard, Treaty Interpretation, New York, OUP, 2008; Fitzmaurice, Gerald, "Vae Victis or Woe to the Negotiators! Your Treaty or Our Interpretation of it”, 65 AJIL 358, 1971.

18 South West Africa (Ethiopia v. South Africa; Liberia v. South Africa) Preliminary Objections, Judgment of 21 December 1962, p. 319; 335; Avena and other Mexican Nationals (Mexico v. USA) Judgment, I.C.J. Reports 2004, p. 12; p. 48, para 84.

19 Legality of the Threat or Use of Nuclear Weapons, Advisory Opinion, ICJ Reports 1996, p. 226, para 70 . 
the Definition of Aggression proclaim the absolute prohibition of the use of force between states.

Moreover, paragraph 3 (b) expresses that subsequent practice of the parties in application of a treaty is also relevant for its interpretation. Although an exhaustive depiction of state practice regarding use of force is outside the purview of this discussion, it is indeed important to ascertain that in exercising such actions, states have consistently justified interventions under the conception that Article 2 (4) is an absolute prohibition. In doing so, they have rather claimed to act as a measure of self-defence or under a SC authorization.

For example, in what constituted the subject matter of the Hostages case, the US notified the SC that its actions in response of the seizure of its embassy in Tehran were measures of self-defence. ${ }^{20}$ It also relied on the exercise of the right of collective self-defence to justify its actions in the Nicaragua case. ${ }^{21}$ Nigeria also justified its use of force under a disputed territory with Cameroon in the Land and Maritime Boundary case, such as Eritrea did before the Eritrea-Ethiopia Claims Commission for its use of force against Ethiopia. ${ }^{22}$ A similar argument was advanced by Uganda in the Armed Activities case, in which the ICJ refused to assert whether the right to self-defence could be exercised as a consequence of attacks committed by non-state actors. ${ }^{23}$

Even in situations in which the applicability of article 51 raises serious doubts, states have relied on the right to self-defence as the legal basis for their actions. This is, for instance, the case of Portugal's interventions during the 60's and 70's in Guinea, Senegal and Zambia as a consequence of terrorist activities. This was also the argument upon which South Africa consistently relied during its interventions in Angola, Botswana, Mozambique and Zambia in the 70's. ${ }^{24}$ Moreover, this has also been the legal basis invoked by Israel for its attacks in Lebanon and in its occupied territories, as was addressed by the ICJ in the Pal-

20 Hostages case, op. cit., 10, p. 18

21 Nicaragua case, op. cit., 6, para 200.

22 Ius Ad Bellum (Partial Award), EECC, 19 December 2005, 45 ILM 430 (2006).

23 Armed Activities case, op. cit., 6, para. 147.

${ }^{24}$ Gray, op.cit.14, 37-138. See also. Alexandrov, Stanimir, Self-Defense Against the Use of Force in International Law, Leiden, Martinus Nijhoff, 1996. 
estinian Wall advisory opinion. ${ }^{25}$ Furthermore, the US also advanced a pre-empitve self-defence argument, inter alia, in the Aerial Incident case arising from the shooting down of an Iranian aircraft and to justify the its actions in Iraq in 2003. ${ }^{26}$

Self-defence has also being the argument for actions undertaken by states for the protection of nationals abroad. Among others, these are the cases of UK's intervention in the Suez canal in 1956, Israel during the Entebbe incident in 1976, France in several African states during the 70s, and the US in Grenada and Panama during the $80 \mathrm{~s} .{ }^{27}$ This argument was also very recently used by Russia to justify its intervention in Georgia in $2008 .^{28}$

It is irrelevant whether such actions were undertaken for protecting human rights, economic interests, counterstrike terrorism activities, or any other reason, since the element that is important for interpreting the prohibition of the use force contained in article 2 (4) is the legal justification that the state addresses for its actions. In this case, states have not claimed a narrow interpretation of such article, but they rather have justified their actions under the exception contained in article 51.

Aside from the exception of self-defence, states have also argued implicit authorizations of the SC. ${ }^{29}$ This was the argument advanced by

25 Legal Consequences of the Construction of a Wall in the Occupied Palestinian Territory, Advisory Opinion, ICJ Reports 2004, p. 136, para 138.

26 Aerial Incident of 3 July 1988 (Islamic Republic of Iran v. United States of America) ICJ Pleadings, vol. I, 91, 212. See also, Yoo, John, "Using Force", 71 Chicago Law Review 729, 2004; Reisman, Michael \& Armstrong, Andrea, "The Past and the Future of the Claim of Preemptive Self-Defence", AJIL 525, 2006; "The Legality Of Anticipatory Self-Defence in the 21st. Century World Order”, 54 Neth ILR 441, 2007.

27 Gray, op. cit., 14, 156-157. See also Ruys, Tom, “'The Protection of Nationals' Doctrine Revisited”, 13 Journal of Conflict and Security Law 233, 2008; Bowett, Derek, “The Use of Force for the Protection of Nationals Abroad", in Cassese, Antonio (ed.), The Current Legal Regulation of the Use of Force, Leiden, Martinus Nijhoff, 1986.

28 Report of the Independent International Fact-Finding Mission on the Conflict in Georgia, September 2009, vol. II, Chapter 6. Available at http://www.ceiig.ch/Report.html, visited in 13 June 2011. The conflict was brought by Georgia to the ICJ, but the Court declined jurisdiction to address the subject matter of the dispute. Application of the International Convention on the Elimination of all Forms of Racial Discrimination (Georgia v. Russian Federation), Preliminary Objections, ICJ, Judgment of 1 April 2011.

29 For debates over the argument of explicit authorization see Sicilianos, LinosAlexander, 'L'autorisation par le conseil de securité de recourrir à la force: une tentative d' 
that France before the SC to address the legality of NATO's actions in $\mathrm{Kosovo}^{30}$, and was also the argument given by the UK to assess the legality of Operation Iraqi Freedom, as a consequence of the Chilcot Inquiry. ${ }^{31}$

Another argument frequently used by African states was that of consent or invitation of the state on which the force was used. Since article 2 (4) prohibit states from using force in their international relations the consent of the territorial state would not imply an exception, but rather the inapplicability of the disposition. ${ }^{32}$ Nevertheless, states have frequently condemned such actions as was the case of Angola's intervention in Congo-Brazzaville and Liberia's and Burkina Faso's in Guinea. ${ }^{33}$ Even if a SC Resolution was not issued, Cuba, China, India, Russia, Ukraine, and Belarus condemned NATO's intervention in Kosovo. ${ }^{34}$ However, condemnation is a political act that bears no relationship with the responsibility of the state, which is composed only by its act and the obligation breached. ${ }^{35}$ As such, condemnation is not needed to assess the legality of the actions of a state. The fact that a state breaches a rule

evaluation", 106 RGDIP 5, 2002; Simma, Bruno, "NATO, the UN and the Use of Force: Legal Aspects", 10 EJIL 1, 1999; Higgins, Rosalyn, "International Law in a Changing International System”, 58 Cambridge Law Journal 78, 1999.

30 SC 3989th Meeting, 1999; 1999 UNYB 343; Lobel, Jules \& Ratner, Michael, "Bypassing the Security Council: Ambiguous Authorizations to Use Force, Cease-fires and the Iraqi Inspection Regime”, 93 AJIL 124, 1999; Kritsiotis, Dino, “The Kosovo Crisis and NATO's Application of Armed Force Against the Federal Republic of Yugoslavia”, 49 ICLQ 330, 2000.

31 United Kingdom Foreign \& Commonwealth Office, "Iraq: Legal Basis for the Use of Force”, 52 ICLQ 2003, 812. See also, Report of Dutch Committee of Inquiry, 57 Neth ILR 81, 2010; Franck, Thomas, "What Happens Now - The United Nations after Iraq", 97 AJIL 607, 2003.

32 Armed Activities case, op. cit., 6, para. 128.

33 Gray, op. cit., 8, 73-74

34 SC 3989th Meeting, 1999; 1999 UNYB 343.

35 See, inter alia, Phosphates in Morocco, Preliminary Objections, 1938, PCIJ, Series A/B, No. 74, p 10, 28; Corfu Channel, Merits, ICJ Reports 1949, p. 4, 22-23; Hostages case. op. cit., 10, 29; Gabcikovo-Nagymaros Project (Hungary/Slovakia), ICJ Reports 1997, p.7, 54. For debates on the effects of subsequent resolutions of the SC in Kosovo see: Franck, Thomas, "Interpretation and Change in the Law of Humanitarian Intervention", in Holzgrefe, J. L. \& Keohane, Robert (eds.) Humanitarian Intervention, Cambridge, Cambridge University Press, 2003, p. 204; Hipold, Peter,"Humanitarian Intervention: Is There a Need for a Legal Repraisal?”, 12 EJIL 437, 2001. 
only reinforces its existence, as affirmed by the ICJ in the Nicaragua case, explicitly in relation to the prohibition of the use of force. ${ }^{36}$

Finally, a claim for humanitarian intervention per se has been scarcely advanced by states to justify the legality of an intervention. ${ }^{37}$ NATO'S campaign in Kosovo was supported only by Slovenia under that basis before the SC. Conversely, the UK and US argued under the basis of necessity at that time. ${ }^{38} \mathrm{~A}$ claim of humanitarian intervention was also advanced by Belgium during the provisional measures phase of the Legality of Use of Force case in which it relied in the precedents of India in Bangladesh, Tanzania in Uganda, and Vietnam in Cambodia, despite de the fact they were all justified under self-defence and condemned by the GA. ${ }^{39}$

In this sense, arguing for the existence of an exception other than the one established in article 51, would need the support of states, through their legal analysis of their own actions. The fact that they have not claimed an interpretation of article 2(4) allowing for the use of force is evidence that states do not believe such exception exists. Conversely, the fact that they generally attempt to justify their actions under the right of self-defence, despite how manifestly illegal or far-fetched they are, reaffirms the status of such right as the only exception to the prohibition of the use of force. This, naturally, also defeats any argument regarding the existence of a rule of customary international law on this subject.

Nevertheless, it is true that in accordance with what has been called as the systemic interpretation principle, an argument can be made to justify the existence of a rule of humanitarian intervention. ${ }^{40}$ Article 313 (c) of the VCLT establishes that other rules of international law

36 Nicaragua case, op. cit., 6, para 186.

37 The UK has supported the doctrine in the last two decades, but it has never justified its actions under such basis. See United Kingdom Foreign \& Commonwealth Office, "Use of ForceUse of Force other than Self-Defence and Under the UN Charter”, 71 BYIL 640, 2000, 646.

38 SC 3989th Meeting, 1999; 1999 UNYB 343.

39 Legality of Use of Force (Yugoslavia v. Belgium), Provisional Measures, Order of 2 June 1999, ICJ Reports 1999, p. 124; Gray, op. cit., 8, pp. 45 and 46.

40 McLachlan, Campbell, "The Principle of Systemic Integration and Article 31 (3) (c) of the Vienna Convention”, 54 ICLQ 2005, 279. See also Koskenniemi, Martti, Fragmentation of International Law: Difficulties Arising From The Diversification and Expansion of International Law, 
relevant between the Parties should be taken into account to interpret a treaty provision. In this regard, international human rights instruments oblige states to protect civilian populations. This is undoubtedly true. However, the obligations arising for states in the International Covenant for Civil and Political Rights, for example, are subject to the condition that persons must be under the jurisdiction of the state. Whereas international human rights instruments may have an extraterritorial applicability, ${ }^{41}$ the state agents acting extraterritorially would only have such obligations when they effectively have jurisdiction over people abroad. The extraterritorial applicability of a human rights treaty cannot be interpreted to constitute a legal entitlement for states to seek that jurisdiction. This would not be justifiable even under the evolutive interpretation principle, ${ }^{42}$ since it would imply modifying the jus scriptum of the UN Charter and human rights treaties for such purpose.

In order for humanitarian intervention to be legal it must be drafted as an explicit exception to the prohibition of the use of force in the UN

Report of the Study Group of the International Law Commission, International Law Commission, Fifty-eight session UN Doc A/CN.4/L.682

41 The extraterritorial application of human rights treaties is still and ongoing debate under international law. See Application of the International Convention on the Elimination of all Forms of Racial Discrimination (Georgia v. Russian Federation), Provisional Measures, Order of 15 October 2008, I.C.J. Reports 2008, p. 353; Legal Consequences of the Construction of a Wall in the Occupied Palestinian Territory, op.cit. 28, para 109-112; Bankovic v. Belgium and other 16 states App no 52207/99 (ECtHR, 12 December 2001) paras 61-69; Loizidou v Turkey [Merits] App no 15318/89 (ECtHR, 18 December 1996) para. 56; Loizidou v Turkey [Preliminary Objections] (ECtHR, 23 March 1995) para. 61; Pereira Montero v. Uruguay, UNHRC, Communication No. 106/1981, U.N. Doc. Supp. No. 40 (A/38/40) (1983) 186, para 10; Lopez Burgos v. Uruguay, UNHRC, Communication No. R.12/52, U.N. Doc. Supp. No. 40 (A/36/40) (1981) 176, para. 12.1; Wilde, Ralph, "Compliance With Human Rights Extraterritorially: 'Human Rights Imperialism?'”, in Boisson de Chazournes, Laurence and Kohen, Marcelo (eds.), International Law and the Quest for its Implementation, Liber AmicorumVera Gowlland-Debbas, Leiden, Martinus Nijhoff, 2010, p. 319; Zimmermann, Andreas, "Extraterritorial Application of Human Rights Treaties. The Case of Israel and the Palestinian Territories Revisited", in Buffard, Isabelle, et al. (eds.), International Law between Universalism and Fragmentation: Festschrift in Honour of Gerhard Hafner, Leiden, Martinus Nijhoff Publishers, 2009, p. 747; Coomans, Fons and Kamminga, Menno, Extraterritorial Application of Human Rights Treaties, Antwerp, Intersentia, 2004; Meron, Theodor, "The Extraterritoriality of Human Rights", 89 AJIL 81, 1995.

42 Golder v United Kingdom App no 4451/70 (ECtHR, 21 February 1975) para. 31. 
Charter, as is the case of article $4(\mathrm{~h})$ of the African Union Charter. ${ }^{43}$ However, such provision in and of itself can at most be considered for the interpretation of the UN Charter and to assess the changing values of the international community, since the global security system is restrained to the actions of the SC and Article 103 of the UN Charter establishes that the obligations under it prevail from those arising from any other international agreement.

Under these circumstances it is evident that the claim for the existence of a right to humanitarian intervention has mainly been an issue of academic debate and not necessarily of actual state practice. Ultimately, as the International Law Commission affirmed, interpreting a treaty is also a task of logic. ${ }^{44}$ In the case of article 2(4) logic dictates that military interventions, as a matter of fact, will inevitably affect the territorial integrity of a state, despite their purposes or duration. ${ }^{45}$ As such, the last phrase of the article should be considered as explanatory and not under the idea that it creates a narrow application for the prohibition of the use of force.

There is no exception to the prohibition of the use of force other than the exercise of the right to self-defence. Even if humanitarian intervention as a concept could have eventually evolved into a rule, practice of states and of the SC suggest it is no longer an option. Conversely, it is only through the SC itself that the use of force for the protection of human rights can be crystallized.

43 Organization of African Union Charter Article 4. "The Union shall function in accordance with the following principles: ... h. The right of the Union to intervene in a Member State pursuant to a decision of the Assembly in respect of grave circumstances, namely war crimes, genocide and crimes against humanity.

${ }^{44}$ International Law Commission, Draft Articles on the Law of Treaties with Commentaries, Yearbook of the International Law Commission, vol II, 1966, 219.

45 Higgins, Rosalyn, Problems and Process: International Law and How We Use It, New York, Oxford University Press, 1995, 240. 
As mentioned before, one of the aspects of the doctrine of Responsibility to Protect is that the SC may authorize the use of force for the protection of human rights, as a measure of last resort. However, Responsibility to Protect is a far more comprehensive theory that comprises not only the use of force, but rather seeks also for the prevention and reparation of gross human rights violations. ${ }^{46}$ The real issue remains on its adequacy with the state of the art of the law for the use of force.

The false question that was advanced in the previous section should be firstly addressed. Could the protection of human rights justify the use of force? Under a Chapter VII scheme the answer is undoubtedly yes. The SC did so since Resolution 221 on the conflict of Southern Rhodesia, ${ }^{47}$ and has consistently continued to authorize force for such purposes. However, the underlying task is to determine under which conditions could the SC authorize the use of force and what are the limits for such authorization.

In accordance with Article 42 of the UN Charter, the SC may authorize the use of force when it has determined that the situation so requires it for the maintenance of international peace and security. In order to do so, the SC must first ascertain whether the situation amounts to a threat to peace, a breach of the peace or an act of aggression, in accordance with Article 39. Neither the categorization of the situation in accordance with Article 39, nor the measures authorized by the SC constitute legal determinations, they are rather the means by which the Council exercises its political functions. ${ }^{48}$

46 See Thakur, Ramesh, The Responsibility To Protect: Norms, Laws, and the Use of Force in International Politics, London, Routledge, 2011; Bellamy, Alex, Global Politics and the Responsibility to Protect, London, Routledge, 2011

47 SC Resolution 221 of 9 April 1966.

48 Gray. op cit., 5, 88. 
Nevertheless, since all SC Resolutions are binding and create obligations to states, ${ }^{49}$ the capacity of the SC to categorize the situation and indicate measures under Chapter VII is not unlimited. ${ }^{50}$ In order to determine the scope of its Chapter VII powers, that SC has to interpret the UN Charter, as one of its implied functions. ${ }^{51}$ Although the SC has a wide discretion to categorize the situation, ${ }^{52}$ it must interpret Article 42 in accordance with the principles and purposes of the UN Charter. ${ }^{53}$ There is a quintessential difference between the reasons that lead the $\mathrm{SC}$ to categorize a situation as a threat or breach to peace or as an act of aggression and its legal capacity to and restrictions to authorize actions.

For instance, lets suppose a state significantly increases its nuclear military capacity solely under the basis of an armament policy implemented by the Minister of Defense that finds no support by other factions of the government. As the practice of the SC reflects, in a situation like that it would normally impose an economic embargo to such state in accordance with Article 41 of the UN Charter. Whereas the ideal measure to repeal such threat would be to order the removal of the incumbent Minister of Defense, the SC would found itself restricted by Article 2(7) as it would constitute a manifest interference with the domestic affairs of a state. In this sense, while the increase in nuclear military capacity constitutes the SC political entitlement to undertake

49 UN Charter. Article 25; Legal Consequences for States of the Continued Presence of South Africa in Namibia (South West Africa) notwithstanding Security Council Resolution 276 (1970), Advisory Opinion, ICJ Reports 1971, p. 16, para. 113 [Hereinafter “Namibia”].

50 Wet, Erika de, Chapter VII Powers of the United Nations Security Council, Oxford and Portlan, Hart Publishing, 2004, 136; Martenczuk, , Bernd "The Security Council, the International Court and Judicial Review: What Lessons from Lockerbie?", 10 EJIL 538, 1999, 543. Supporting the contrary see, Gowlland-Debbas, Vera, "Security Council Enforcement Action and Issues of State Responsibility" 43 ICLQ 1994, 60.

${ }^{51}$ Reparatios, op. cit., 16, 180.

52 Gill, Terry, "Legal and Some Political Limitations on the Power of the UN Security Council to Exercise its Enforcement Powers Under Chapter VII of the Charter”, 26 NYIL 40, 1995.

53 UN Charter, Article 24 (2) VCLT, Article 31 (2), Kelsen, Hans, Principles of International Law, London Rinehart \& Company, Inc, 1952, 730; Frowein, Jochen, \& Krisch, Nico, "Chapter VII. Actions with Respect to Threats to Peace, Breaches of the Peace, and Acts of Aggression”, in Simma, Bruno (ed.), The Charter of the United Nations: A Commentary, New York, OUP, 701,711 
actions, the reserved domain of the state's jurisdiction constitutes its legal boundary.

A similar situation occurs with SC authorizations of the use of force for the protection of human rights. Whereas systematic violations of human rights may constitute a threat to peace under Article 39, the extent of the capacity of the SC to authorize the use of force to repeal the threat is legally restricted by other dispositions of the UN Charter. In particular, the principle of territorial integrity as an extension of the principle of state sovereignty, contained in Article 2(1), constitutes the ultimate legal restriction of the Council's capacity to authorize the use of force in such circumstances. As such, in order to so, it requires the consent of the territorial state.

The abovementioned, of course, is not an obvious assumption, but it can be derived from and analysis of the differences between the original scheme of the Charter and how the SC has adapted its interpretation to face the current threats to the international community.

In the original scheme of the UN Charter, the Council was ideated as the entity that would deal with inter-state conflicts in order to avoid unilateral use of force and facilitate the peaceful settlement of international disputes. ${ }^{54}$ In this sense, the capacity to authorize force was granted as a measure of last resort to restore peace only in relations between states, as the plain text of Article 42 confirms by introducing the term "international". ${ }^{55}$ Only under these circumstances did the SC have the capacity to authorize the use of force against the territory of another state. It was not the purpose of the Organization to restore peace in intra-state conflicts. ${ }^{56}$

54 Kelsen, Hans, The Law of the United Nations, London, Steven \& Sons Ltd, 1950, 744

55 The SC has only authorized the use of force in inter-state conflicts twice. In the Korean War (SC Resolution 83 of 27 June 1950) and as a consequence of the Iraqi intervention in Kuwait (SC Resolution 678 of 29 November 1980). This resolution was later asserted by some commentators to be the start of the "New World Order". See Greenwood, Christopher, "New World Order or Old? The Invasion of Kuwait and the Rule of Law", 55 The Modern Law Review 153, 1992.

56 Kelsen, op. cit., 54, 15. The terms "intra-state" and "inter-state" conflicts are used to avoid the discussion regarding the elements necessary for the existence of an "international armed conflict" or a "non-international armed conflict" as addressed by common articles 2 and 3 of the Geneva Conventions and their Additional Protocols 1 and 2. The former will be 
As the concerns of the international community have evolved, the Council has done so too by adjusting its practice to address them. This is the case of how it interprets human rights and the failure to protect them as an emerging principle of international law capable of constitute as having effects in the collective security system. ${ }^{57}$ This is evident from the fact that, although the disposition was originally not intended to refer to such situations, the SC now categorizes intra-state conflicts as a threat to peace under Article $39 .{ }^{58}$ Never theless, the Council has also been aware that a change in the situation does not imply a change of the jus scriptum of the UN Charter. Since its capacity to authorize force is restricted by Article 42 to restore international peace, it has adjusted such power only to the extent that the principle of sovereign equality of states, contained in Article 2(1), is not breached. Being territorial integrity the natural extension of such principle, the SC has consistently avoided authorizing the use of force for the protection of human rights within the territory of a state or without its consent.

The first example of this interpretation can also bee seen in SC Resolution 221. ${ }^{59}$ The Resolution was issued as a consequence of an internal conflict in Southern Rhodesia in 1966. Whereas the SC categorized the situation as a threat to peace, it only authorized the UK to use force in order to prevent the arrival of vessels to Beira that were believed to be carrying oil to Southern Rhodesia. Moreover, had the UK not been able to prevent the arrival, the resolution only authorized it to detain the tankers upon their departure from Beira. The fact that the Council did not authorize enforcement actions within the territory of Southern Rhodesia, but rather to prevent or capture the vessels outside of it, is evidence that it was interpreting its Article 42 powers privileging the territorial integrity of the state.

used to refer a conflict between the military forces of two states and the latter to refer to a conflict between the state and a national liberation movement or insurrection, or to a civil war.

57 Cot, Jean-Pierre et al., Le Charte des Nations Unies. Commentaire article par article, 3rd ed., Paris, Economica, 2005, 899.

58 Frank, Thomas, Fairness in International Law and Institutions, New York, OUP, 2005, pp. 224-231.

59 SC Resolution 221 of 9 April 1966. 
Consent of the territorial state has proven to be an implicit requisite for the Council to authorize the use of force in intra-state conflicts. The SC has authorized the use of force for the protection of human rights within the territory of a state under three schemes: 1) as a consequence of a direct request; 2) as a measure to enforce an agreement between parties to a conflict or previous resolution, and; 3) in transitional situations. These schemes are hereby analyzed.

\section{Direct request}

The first of these schemes can be seen in the situation in the Central African Republic in 1997. In that case, following a request of the government, the SC authorized under Resolution 1125 the deployment of a multinational force to ensure the security and freedom of movement of the Inter-African Mission to monitor the Implementation of the Bangui Agreements. ${ }^{60}$ This was also the case when in 1999 , pursuant to a request of the government of Indonesia, the SC established a multinational force to restore peace and security in East Timor. ${ }^{61}$

The same scheme can be seen in 2003 in relation with the situation in the Democratic Republic of Congo. Despite the Lusaka Peace Agreements, peace was not restored in the Great Lakes Region and upon recommendation of the UN Secretary General, the Democratic Republic of Congo, the parties in the Ituri conflict, Uganda and Rwanda requested the SC to authorize a multinational force. As such, under Resolution 1484, the Council authorized the deployment of an Interim Emergency Multinational Force in Bunia in order to, inter alia, contribute to the stabilization of the security conditions and the improvement of the humanitarian situation and the safety of civilian population. ${ }^{62}$

The SC very recently adopted this scheme for the authorization for the use of force due to the crisis with the Somali pirates. Under Reso-

60 SC Resolution 1125 of 6 August 1997.

${ }^{61}$ SC Resolution 1164 of 15 September 1999. It is possible to argue that Indonesia had no such capacity, as the legal status of East Timor was debatable. See. East Timor (Portugal v. Australia), Judgment, I.C.J. Reports 1995, p. 90.

62 SC Resolution 1484 of 14 May 2003. 
lution 1846 and upon request of the Somali government, the Council authorized states and regional organizations to, inter alia, enter into the territorial waters of Somalia for the purpose of repressing acts of piracy and armed robbery at sea. ${ }^{63}$

The abovementioned constitute relatively simple examples on how the SC authorizes the use of force when it has consent of the territorial state. However, the Council has also shown that when it has doubts of the capacity of the government to give such consent, it has preferred to only authorize measures outside the territory of the state. This occurred in Sierra Leone where even though a military junta overthrew the democratically elected government, the SC only authorized ECOWAS to halt maritime shipping outside the territory of the state. ${ }^{64}$

The quintessential example on how, unfortunately, consent of the territorial state is needed for the SC to authorize the use of force for the protection of human rights in its territory is the case of Darfur and its surrounding states. As a consequence of the humanitarian crisis in 2004 the SC issued a series of resolutions imposing sanctions against the government of Sudan for actions taken against its civilian population. This included economic sanctions, an arms embargo, and the referral of the situation to the International Criminal Court. ${ }^{65}$ Although it was not explicitly argued as such, the Security Council was restricted by the consent of the government of Sudan to deploy forces. In these circumstances, such measure couldn't be authorized to prevent the humanitarian catastrophe. Evidence of that is that when the conflict spread to Chad and the Central African Republic, the Council was able to authorize a multinational presence because those states consented to it. ${ }^{66}$

\section{Implementation of previous resolutions or agreements between parties}

This scheme implies the existence of a previous legal basis to take enforcement actions. This means that even though states have not consen-

63 SC Resolution 1846 of 2 December 2008.

64 SC Resolution 1132 of 8 October 1997.

65 SC Resolutions 1156 of 30 July 2004, 1564 of 18 September 2004, and 1593 of 31 March 2005.

66 SC Resolution 1778 of 25 September 2007. 
ted to a multinational force in their territory, they have nevertheless previously consented or agreed to other forms of actions where the use of force was authorized. In this sense, when the SC has authorized force under this scheme, it has done so under the indirect consent of the state.

The first form in which the SC has authorized force under this scheme is to implement an agreement between the parties of a conflict. This occurred in 1994 in Haiti, where the Council authorized a multinational force to implement the Government Island Agreement in which the military junta that performed the coup had previously consented to the establishment of a peacekeeping mission and later attacked it at its arrival. After the junta's refusal, the SC authorized a multinational force to help the peacekeeping mission fulfill its mandate. ${ }^{67}$

The SC adopted the same scheme in 1999 at the Balkans. NATO's intervention in Kosovo was followed by an agreement between the parties in which Yugoslavia accepted to withdraw its forces and the creation of a multinational force to establish a safe environment for the people of Kosovo. This force was named KFOR and was authorized by the SC in Resolution 1244. ${ }^{68}$

Moreover, this was also the case in Côte d' Ivoire. After a coup attempt in September 2003, the government of Côte d'Ivoire agreed with ECOWAS' and French forces to intervene. Even though a ceasefire between the different parties to the conflict was reached in January 2003 in the Linas-Marcoussis Agreement, unrest continued in the area. In Resolution 1464, the Council endorsed the original agreement between the government, ECOWAS and France and authorized member states to support them to ensure the protection of civilians. ${ }^{69}$ The SC again authorized these measures when an UN peacekeeping mission substituted ECOWAS forces in 2004. ${ }^{70}$

The second form in which this sort of authorization can be seen is for the enforcement of a previous SC resolution. This has always occurred

67 SC Resolution 940 of 31 July 1994.

68 SC Resolution 1244 of 10 June 1999.

69 SC Resolution 1464 of 4 February 2003.

70 SC Resolution 1528 of 27 February 2004. 
in cases where force is authorized to help a peacekeeping mission to fulfill its mandate.

The first time the Council authorized force for the implementation of a previous resolution was in 1992 . Under resolution 770 , the SC authorized NATO member states to use force in order to facilitate UNPROFOR develop its mandate. ${ }^{71}$ This was also the scheme adopted by the SC in Resolution 794 in which a multilateral force was authorized to allow the peacekeeping mission in Somalia to fulfill its mandate and create a secure environment for humanitarian relief. ${ }^{72}$ The Council also authorized force under this scheme for humanitarian purposes during the conflict in Rwanda in $1994 .{ }^{73}$

The fundamental principle for the establishment of a peacekeeping mission is the consent of the territorial state. ${ }^{74}$ So, as the practice of the SC reflects, it has interpreted its Article 42 powers in this regard, in the sense that once the state has consented to peacekeeping mission in its territory, it has the capacity to authorize force to secure the mandate.

\section{Transitional situations/Absence of an entity capable to consent}

The SC has adopted this scheme and authorized the use of force when the state has no government or it has collapsed. It did so in Haiti in 2004, but only after it was sure that President Aristide had left the country. ${ }^{75}$ In a similar situation, and under pressure of the international community, it only authorized the use of force in the territory of Liberia to implement the peace agreements between the parties to the conflict when it was confident that President Taylor would depart. ${ }^{76}$ This was also the

71 SC Resolution 770 of 13 August 1992.

72 SC Resolution 794 of 3 December 1992.

73 SC Resolution 9925 of 8 June 1994.

${ }^{74}$ Certain expenses of the United Nations (Article 17, paragraph 2, of the Charter), op. cit., 8, 163. See also Higgins, Rosalyn, United Nations Peacekeeping, New York, OUP, 1981.

75 SC Resolution 1529 of 29 February of 2004.

76 SC Resolution 1997 of 1 August 2004. 
scheme it adopted in Albania for explicit humanitarian purposes after the collapse of the government. ${ }^{77}$

A similar situation occurred in Afghanistan after Operation Enduring Freedom. After the overthrow of the Taliban regime, the SC authorized in Resolution 1386 the creation International Security Assistance Force to protect the UN staff peace-building personnel and to secure the protection of Kabul and other surrounding areas. ${ }^{78}$

As a matter of law, this is by far the more controversial scheme in which the SC may authorize the use of force within the territory of one state. Under international law, only a government is capable of representing a state. ${ }^{79}$ However, the overthrow of a government does not imply the collapse of a state. ${ }^{80}$ In practice this entails that until no government is in place, there is no entity that can give consent of behalf of a state. In this scenario the principle of state sovereignty still governs the relations between states. As such, the only explanation for a Council authorization for the use of force in the abovementioned cases is an evolutive interpretation of the UN Charter, in light of extreme circumstances. Nevertheless, those examples are indeed relevant to determine the changing patterns of the SC assessments which led to SC Resolution 1973.

As can be envisaged from all the above-mentioned examples, consent of the state whether direct or indirect is the necessary element for the $\mathrm{SC}$ to authorize use of force in intra-state conflicts. However, it must also be said be said that it is not evident whether the Council restrains itself explicitly under this legal impediment or whether it has done so only for political considerations. Even if the latter was the case, the quid pro quo scheme in which the SC operates between East and West has always shown that territorial integrity, whether implicitly or explicitly,

77 SC Resolution 1101 of 28 March 1997.

78 SC Resolution 1386 of 13 December 2001.

79 Application of the Convention on the Prevention and Punishment of the Crime of Genocide, Preliminary Objections, Judgment, I. C. J. Reports 1996, p. 595, 621-622. Brownlie, Ian, Principles of Public International Law, 7 ed., New York, OUP, 2008, 71.

80 Crawford, James, The Creation of States in International Law, 2ed, New York, OUP, 2006, 34; Jessup, Philip, A Modern Law of Nations, New York, Macmillan Company, 1948, 43. See also Talmon, Stephan, Recognition of Governments in International Law, New York, OUP, 1998. 
seems to be the last limit of action. Nevertheless, under an evolutive understanding of the role of the Organization and of the Council itself, the former is an interpretation which duly integrates the original jus scriptum of the UN Charter to the current paradigms of the international community that the SC has to deal with. At the end of the day, the fact is that the Council has never authorized force in the territory of a state against its will.

The abovementioned is reasonable if it is understood that measures under Article 42 did not originally empower the SC to take actions in intra-state conflicts, as they were intended to be domestic affairs of states in accordance with Article 2(7). As the international community has evolved, the SC has done so too. However, if the states themselves guide their relations under the principle of state sovereignty, it would be unreasonable that the $\mathrm{SC}$ adjusts its powers to undermine it. It is true that the $\mathrm{SC}$ was constituted as the entity empowered to maintain international peace and security, but that is not a legal a basis to undermine the very same principle under which the UN was ideated and international relations are governed.

\section{RESOLUTION 1973: A FUNDAMENTAL CHANGE}

The beginning of 2011 was marked by numerous civil uprisings throughout the Arab world. In mid-February massive protests began in Benghazi, Lybia's second largest city, against the regime of Colonel Muammar el-Qaddafi, which later spread to Tripoli. The government responded to such demonstrations with unseen violence and Colonel Qaddafi repeatedly affirmed that no matter how many people were killed, he would not step down as head of the Libyan state.

The issue was brought to the attention of the SC and under Resolution 1970 it deplored the systematic human rights violations committed by forces loyal to Colonel Qaddafi and reaffirmed Libya's responsibility to protect its population. Furthermore, the SC demanded an immediate cessation of violence, imposed several sanctions upon Libya and Colo- 
nel Qaddafi, and referred the situation to the International Criminal Court. ${ }^{81}$

Due to the escalation of violence and Libya's incompliance with Resolution 1970, the SC issued Resolution 1973. This resolution reiterates the doctrine of Responsibility to Protect and reaffirms the Council's strong commitment with the sovereignty and territorial integrity of Libya. However, the resolution also authorized UN Member States to 'take all necessary measures... to protect civilians and civilian populated areas under threat of attack in the Libyan Arab Jamahiriya, including Benghazi, while excluding a foreign occupation force of any form on any part of Libyan territory'. ${ }^{82}$ The SC requested no consultation or consent to Libya.

The ICJ asserted in its Namibia advisory opinion that a SC resolution has to be interpreted having regard to its terms, the discussions that lead to it, the UN Charter provisions invoked, and any other relevant fact. ${ }^{83}$ As previously referred, Resolution 1973 explicitly recalls in its preamble the doctrine of Responsibility to Protect and reaffirms Libya's territorial integrity. Nevertheless, acting under Chapter VII, on operative clause 4, the SC inter alia authorized 'all necessary measures' to protect civilian population and the established and a no fly zone. The resolution was adopted with ten votes in favor and 5 abstentions, including those of Russia and China.

In the discussions leading up to the resolution, Susan Rice, speaking on behalf the US, affirmed that the SC intended to protect Libyan civilians after the gross and systematic violations of Colonel Qaddafi's regime. The UK representative, Mark Lyall Grant, submitted that the resolution 'put the United Nations clearly behind the highest values of the Organization.” Similar statements were made by the representatives of South Africa, Bosnia and Herzegovina, Portugal, Colombia, and Nigeria. $^{84}$

The delegates of France and Germany underlined that the resolution was also adopted for pro-democratic purposes, and in a rather striking

81 SC Resolution 1970 of 26 February 2011.

82 SC Resolution 1973 of 17 March 2011.

83 Namibia, op. cit., 49, para. 114.

${ }^{84}$ SC 6498th meeting, 17 March 2011, UN Doc. S/PV.6498 
statement, the latter said that 'the Security Council's intention was to stop the violence in Libya and to send a message to Colonel Qaddafi and his associates "that their time is over [and] they must relinquish power immediately'. ${ }^{85}$

The representative of Lebanon affirmed that text of the resolution "would not result in the occupation of "one inch" of Libyan territory by foreign forces'. The delegates of India and Brazil asserted that the measures ordered by the SC were far more reaching from the ones required, as the use of force would not entail a solution to the conflict. ${ }^{86}$

Finally, the delegates of Russia and China explained their abstention in the sense that even though they regretted the humanitarian situation in Libya, the resolution was issued not in keeping with the SC practice and leaving many questions on how it was going to be implemented.$^{87}$

Under a purely legal perspective, several conclusions can be derived from Resolution 1973 in regard to the current status of the law applicable to the use of force and its relationship with the protection of human rights.

First, the Resolution reinforces the notion that two legal regimes for the use of force exist under the Charter and that Council's authorizations are not per se an exception to the prohibition contained in Article 2(4). As submitted by the ICJ in its Namibia advisory opinion, the legal provisions invoked by the $\mathrm{SC}$ in a resolution are elements to take into consideration for its interpretation. In authorizing the use of force under operative clause 4 , the Council based such capacity solely under Chapter VII of the Charter. If the SC had invoked Article 2(4) it would have implied that the entity considered such disposition as one applicable to it capacities under the UN Charter. As elaborated in Section I, this is not the case. Nevertheless, this has always been the posture adopted by the SC and it has only been a confusion under academic circles.

However, it is not possible to derive from Resolution 1973, or from any other resolution on the matter, that the use of force or its authoriza-

${ }^{85}$ Idem.
${ }_{8}$ Idem.
${ }^{86}$ Idem.
${ }^{87}$ Idem. 
tion is restricted to the Council. Precisely, as there exist two dichotomous legal regimes under the UN Charter, such conclusion can only be advanced if they are analyzed separately, as it was done under Sections I and II of this paper.

Second, gross violations of human rights constitute a threat to peace — as referred by Article 39- capable of empowering the SC to authorize the use of force for its repeal. It is clear from the text of the preamble of Resolution 1973 that the attacks on civilian population and human rights violations committed by the Libyan government, were the reasons why the SC authorized the used of force on Libyan territory. No other factors explicitly motivated the Council to the resolution. As explained in Section II, the interpretation that the SC has given to its role and capacities under the UN Charter has evolved in order to adjust to the current conundrums of the international community. In accordance with its previous practice and interpretation of the UN Charter, Resolution 1973 restates the Council's capacity to authorize the use of force to repeal gross and systematic violations of human rights.

Third, the SC omitted the restrictions applicable to its capacity to authorize the use of force. As mentioned before, there is quintessential difference between the situations that allow the SC to authorize the use of force and the legal restrictions to undertake such measures. Whereas the protection of human rights allows the Council to authorize the use of force, the UN Charter delimits the scope of such capacity to situations in which the territorial state has consented to it. Under Resolution 1973 the Council authorized the use of force without the consent of Libya.

There is very little to conclude from the legal provisions invoked by the Council in Resolution 1973 in order to authorize the use of force. As it is usual under the SC's practice, in a situation like such it would only refer to Chapter VII of the UN Charter without even specifying the concrete disposition from which its capacity derives. The SC is an organ of an international organization which, as any other, can only act if it's legally empowered to do so. Despite the role of the United Nations, it is unreasonable to believe that the capacities of the Council are unlimited since that would position it over the Member States, instead of being a forum for the prevention and resolution of conflicts. Such 
interpretation cannot be derived from the text of the UN Charter nor from the intention its Member States. However, despite the lack of legal provisions invoked, if Resolution 1973 is compared with previous similar resolutions it can be concluded that the Council altered its interpretation of the scope of its capacity to authorize the use of force, by omitting the restriction of the consent of the territorial state.

As described in Section II, consent of the territorial constitutes a fundamental element to take into consideration for the authorizations of the use of force. The SC didn't have to face this restriction in several occasions, since the use of force was directly requested by the territorial state in order to restore peace over a situation. This was not the case of the situation of Libya since Colonel Qaddafi's regime explicitly condemned any action of the Council on the matter.

However, when the situation so required it and a direct request of the territorial state was lacking, the Council also found ways to authorize the use of force by relying in some sort of indirect consent. This occurred when states had previously consented to some sort of intervention, such as a peacekeeping mission, through an agreement or a previous resolution and force was later needed to fully implement them. Examples of the former are the cases of Haiti (1994), Kosovo (1999), and Côte d' Ivoire (2004). The situations in Bosnia \& Herzegovina (1992), Somalia (1992), and Rwanda (1994) constitute examples of the latter. In the case of Libya there hadn't been any previous agreement or resolution in which consent to some sort of use of force in the territorial state was given. As such, the SC didn't have any previous legal basis to justify the intervention.

Moreover, the Council also circumvented the requirement in situations in which the state lacked of an entity capable of giving its consent. In the absence of government, the SC interpreted the situation as allowing it to act. This occurred in Albania (1997), Afghanistan (2001), Haiti (2004), and Liberia (2004). At all relevant times the Libyan government exercised its authority over the situation and, consequently, such argument couldn't be invoked to justify the SC authorization.

Finally, some commentators interpret the situation that occurred in Somalia in 1992 as the first in which the SC authorized the use of force 
for humanitarian purposes without the consent of the territorial state. ${ }^{88}$ If clause 11 of Resolution 794, in which the Council asked Member States to provide military forces to establish a secure environment to provide humanitarian relief in Somalia, is read in isolation, the abovementioned is possible to conclude. However such method of interpretation is not adequate and the conclusion is not accurate.

In such resolution the Council invoked Resolution 733, in which the SC explicitly affirmed that the government of Somalia requested it to consider the situation in Somalia, and Resolution 751, in which the peacekeeping mission for Somalia, UNOSOM, was established. ${ }^{89}$ Several paragraphs of the preamble of Resolution 794 further refer to UNOSOM's incapacity to prevent the deterioration of the situation and the verbatim records of the Council debates also refer such concern. If these circumstances are taken into consideration, it cannot be unequivocally submitted that the SC circumvented the requirement of consent since it was requested by Somalia to consider the situation and since it consented to the establishment UNOSOM.

Furthermore, the SC mentions in operative clause 7 that actions under Chapter VII are consequence of the recommendations of the Secretary-General issued in his letter S/24868. In such letter the SecretaryGeneral explicitly asked the Council to authorize the use of force as a consequence of the lack of government in Somalia. ${ }^{90}$ In such circumstances, even if the authorization of the use of force in Somalia found its basis on purely humanitarian purposes, as scholars suggest, the legal capacity of the Council was based on the consent previously given by Somalia to analyze the situation, the establishment of a peacekeeping mission and the inability to provide consent at the specific time of the measure. This implies that the situation of Somalia constituted both one of indirect request and one of absence of entity capable of giving its consent.

${ }_{88}$ See inter alia, Welsh, Jeniffer M, "The Security Council and Humanitarian Intervention”, in Lowe, Vaughan, et al. (eds.), The United Nations Security Council and War, New York, OUP, 2008, 535, 539 .

89 SC Resolution 751 of 24 April 1992.

90 Letter Dated 29 November 1992 from the Secretary-General Adressed to the President of the Security Council. UN Doc. S/24868. 
In contrast with the situation of Somalia in which the government was at all times willful to cooperate with the Council, the situation in Libya constituted the first time in which it acted against the will of the territorial state and without its consent. This confirms how the Council obviated the restrictions applicable to it capacity to authorize the use of force to repeal gross and systematic violations of human rights in intrastate conflicts.

The abovementioned cannot be considered just as a deviation from the practice of the SC, as delegates of Russia and China highlighted during the debates. A much more profound change has occurred. The SC altered its interpretation of the UN Charter to privilege the protection of human rights over the principle of state sovereignty for the very first time. As can be seen from the French delegate's statement, the spirit that reigned the discussions was that of the Council acting in accordance with the current status of the principles of the United Nations.

Although human rights are believed to be a fundamental principle of the international legal system, the principle of consent, as an extension of the principle of state sovereignty had always been privileged over them. ${ }^{91}$ This may be one time in which such relationship was reversed. It seems unlikely that states will endorse such interpretation under a situation different from international community security matters and under the limited framework of the SC action. Nevertheless, this is also evidence on how international law evolves and its principles can be interpreted systemically to adjust to the current demands and aspirations of the international community. Whereas legislative changes over the text of the UN Charter through interpretation will never be desirable, an interpretation that seeks to bridge the fabrics of the international legal order will always be.

Two major legal consequences can emerge from this precedent. First, if the regimes for the use of force are not understood by states as mutually exclusive- despite the text of the UN Charter-they may find this as valid precedent for unilaterally intervene in order to protect human

91 See Reservations to the Convention to the Convention on Genocide, Advisory Opinion, ICJ Reports 1951, p. 15; East Timor (Portugal v. Australia), Judgment, ICJ Reports 1995, p. 90; Armed Activities on the Territory of the Congo (New Application : 2002) (Democratic Republic of the Congo v. Rwanda), Jurisdiction and Admissibility, Judgment, ICJ Reports 2006, p. 6. 
rights. This, given the circumstances, may eventually imply a different interpretation of Article 2(4). Nevertheless, such conception is neither desirable, nor would be legally correct. Second, the SC would no longer have any legal restriction to authorize the use of force and would only be subject to its political considerations under Article 39 and the check and balances within the Council itself.

It is evident that the international community is not willing to carry the burden of another Sebrenica or Darfur, and the response of the Council to the Libyan situation may be evidence of the changes that the principles that govern international relations are facing. However, this precedent also poses questions on the nature of the SC and its capacity to interpret and apply the rules that govern the international community, beyond its own mandate. It is still premature to envisage the concrete legal consequences that resolution 1973 may bring to the structure of international law.

Nevertheless, despite how questionable it may be that the SC is the entity interpreting the current status of the principles of international law, the political balances within it may also function as the best restrictions against an "over interpretation" or legislation of the text of the UN Charter.

In the political arena, questions on the capacity of the Council to authorize missions that extend from the protection of human rights to the instauration of pro-democratic regimes and NATO's function in such campaigns are already been posted. Questions on the legal effects of such actions and how the structure of the United Nations and the international community itself are affected are ought to be asked too in the near future.

Nevertheless, it seems that a new chapter in the history of the SC has begun and only one is thing certain: the game has changed. 